\title{
Species Diversity in Coconut (Cocos nucifera) based Agroforestry System in Coastal Odisha
}

\author{
S. K. Sarangi ${ }^{1 *}$, N. K. Panda ${ }^{2 *}$ and N. Bhol ${ }^{2}$ \\ ${ }^{1}$ Shristi NGO, Keonjhar, Odisha, India \\ ${ }^{2}$ Department of Silviculture \& Agroforestry, College of Forestry, Odisha University of \\ Agriculture \& Technology, Bhubaneswar, Odisha, India \\ *Corresponding author
}

\section{A B S T R A C T}

\begin{tabular}{l}
\hline Ke y w o r d s \\
Coconut, \\
Agroforestry, \\
Species diversity, \\
Composition, \\
Pisciculture, \\
Mushroom \\
cultivation, Odisha \\
\hline Article Info \\
\hline $\begin{array}{l}\text { Accepted: } \\
\text { 10 July } 2020 \\
\text { Available Online: } \\
\text { 10 August } 2020\end{array}$ \\
\hline
\end{tabular}

This study carried out in Puri district of Odisha during June 2015 - May 2016 to determine the species diversity in coconut based agroforestry system in 15 different sizes ( 0.1 to 1.5 acre) of land holdings. The chosen coconut based agroforestry systems were visited in three cropping seasons such as kharif, rabi and summer and the observations on floral composition, height of plants, number of trees, number of livestock animals and birds, number of common plant species, different seasonal crops, different size of pond and mushroom cultivation were recorded. There are four different strata in which different perennial species were associated with coconut. The strata are more than $15 \mathrm{~m}, 10-15 \mathrm{~m}, 5-$ $10 \mathrm{~m}$ and less than $5 \mathrm{~m}$. The number of common perennial species like coconut trees found in this system ranged from 25-118, timber species ranged from 3-6 and fruit species ranged from 2-7 along with various annual and seasonal crops. The total number of livestock animals increased from 4-9 per holding among the different coconut based agroforestry system studied with an increasing trend from small holdings to large holding up to 0.8 acre. In case of birds, ducks were found to be reared where backyard pond is available while poultry birds were reared in small holdings. Pisciculture were found in relatively small holdings from 0.1 acre to 1.2 acre and mushroom cultivation was practiced by middle size holding ranged from 0.4 acre to $1.0 \mathrm{acre}$. The coconut based agroforestry system of size 0.8 acre was found to be best among the holding sizes studied with regard to species diversity.

\section{Introduction}

Coconut (Cocos nucifera) plays a significant role in the agrarian economy of India. Coconut is grown in more than 93 countries of the world in an area of 12.29 million ha with a total production in terms of copra equivalent of 11.04 million MT. Indonesia
(25.63\%), Philippines (23.91\%) and India $(19.20 \%)$ are the major coconut producing countries of the world. Coconut based agroforestry means agriculture along with woody component with coconut plant as a compulsory. In India the coconut based agroforestry are generally found in tropical and sub-tropical areas and characterized by 
high species diversity and usually three to four vertical canopy strata. These agroforestry systems consist of different layer of species starting from seasonal crops, perennial crops, woddy components. The lower most being dominated by different vegetables like brinjal, greens, turmeric, ginger, mushroom, okra, chilli, tomato, cabbage, dioscorea, etc and the second layer is comprising food plants such as banana, papaya, lemon, etc. The third layer is occupied by fruit trees like guava, drumstick, custard apple, etc. The upper layer is the tree layer which can be divided into two, consisting of the emergent full grown timber and fruit trees having height more than $20 \mathrm{~m}$ and medium size trees of $10-20 \mathrm{~m}$. In the upper layer species like Mangifera indica, Samanea saman, Bambusa vulgaris, B. tulda, Cocos nucifera, Areca catechu, Samania saman, Artocarpus heterophyllus, Aegle mormalus, Tamarindus indica, Azadirachta indica, Leucaena leucocephala, etc. are grown. In developing countries particularly in India coconut is either grown as mono-crop or as major component in the multiple cropping systems with or without livestock. In Odisha it occupies more than $60 \%$ of the perennial crop area and more than $30 \%$ of the total cropped area in costal districts mostly Puri, Jagtsingpur, Balasore, Kendrapada and Khurda. The coconut farming system is very promising as spacing is wide, the system affords higher incidence of light under the canopy and the limited effective root zone of the coconuts allows other crops within the grove. Especially in the costal part of the district, vast lowland and homestead land areas are being planted with coconut. The advent of population pressure, less lands to cultivate and the worsening marginal conditions of farmlands prompt the need to go into farming systems that would optimize use of the limited land resource, thus intercropping, a form of agroforestry gained popularity among farmers. Basing on this background, an attempt was taken to assess the species diversity in coconut based agroforestry system of coastal Odisha.

\section{Materials and Methods}

The present study was carried out in the Puri district of Odisha, a coastal district along the Bay of Bengal during June 2015 - May 2016. The experiment was laid out in Randomised Block Design (RBD) with three replications. For this the district was divided into three regions, each region represented one replication. The region-I covered the eastern part of the Puri district comprising four blocks such as Gop, Kaktpur, Astaranga and Puri. The region-II covered North central part of the district comprising Pipili, Delanga, Satyabadi and Kanasa blocks. The region-III covered the western part of the district comprising Chilika, Krushnaprasad and Brahmagiri blocks. In each region, the structural characteristics under coconut based agroforestry of 15 different sizes were studied. The observations were recorded on floral composition, number of common plant species, height of plants growing in different strata, number of trees and number of livestock animals and birds in coconut based agroforestry system.

\section{Results and Discussion}

\section{Common perennial species in different} strata of coconut based agroforestry system

The coconut based agroforestry systems studied in fifteen different land holding sizes witnessed broadly four different strata in which different perennial species were associated with coconut. The strata are more than $15 \mathrm{~m}, 10-15 \mathrm{~m}, 5-10 \mathrm{~m}$ and less than $5 \mathrm{~m}$. In all holding size coconut occupied the top most storey $(>15 \mathrm{~m})$. Between the holding size of $\mathrm{T}_{3}$ and $\mathrm{T}_{10}$ the common tree species associated in these strata were siris, rain trees, eucalyptus and karanj. In the holding size of 
1.1acre and above no perennial plant was found with coconut. In very small holding size like $T_{1}$ and $T_{2}$ the presence of other trees were zero or negligible because of not availability of space. In relatively higher size holding $\left(T_{12}\right.$ to $\left.T_{15}\right)$ no other trees were associated because in such holdings sizes paddy is grown which needs more access to light. In the strata of $10-15 \mathrm{~m}$ height the common perennial plants were arecanut, mango and bamboo up to 1.2acre size holding. In relatively higher size holding within this limit $\left(T_{3}\right.$ to $\left.T_{12}\right)$ additional species like acacia, teak and jackfruit are grown. No perennial trees are found in the holding size $\mathrm{T}_{13}$ to $\mathrm{T}_{15}$ other than coconut in these strata. People grow these perennial trees along with coconut depending upon holding size to meet various requirements like food, fodder, fuel, timber etc. in addition to get a congenial microclimate and generate additional money and employment on the same land holding. In the strata 5-10m height mostly crops were in different holding sizes of coconut based agroforestry system. In small size holding like $\mathrm{T}_{1}$ and $\mathrm{T}_{2}$ drumstick, papaya and guava are found commonly. In relation to higher holdings size like $T_{3}$ to $T_{12}$ the common perennial plants were guava, papaya, pomegranate, drumstick and bael. People have grown these plants in different sizes of holding primarily to supplement the food from these plants. The wider spacing of coconut favors growing these fruit plants under it. In the strata of less than $5 \mathrm{~m}$ height the common plants are citrus, banana and curry leaf from $T_{1}$ to $T_{12}$ holding size. People are deliberately kept these plants to get food and leaf from these plants which are frequently required in household of rural people. In holding size 1.3 acre to 1.5 acre no associated perennial plants were found associated with coconut in any strata. This is because the higher size holding are mostly used for coconut paddy cropping system in the district. Different plants have occupied in different strata may be due their growth rate, light requirement and deliberate arrangement by the grower to intensify the coconut based land use system and explore maximum benefit. Similar study have been reported by (Rahaman et al., 2013), (Nair, 2008) and (Fernades et al., 1984).

\section{Number of perennial plant in coconut based agroforestry}

The number of common perennial plant species including coconut, timber species and fruit species other than coconut varied remarkably in the coconut based agroforestry system of Puri district (Table 1). The number of coconut trees per holding varied from 25 to 118 with an increasing number towards higher size units. The number of coconut trees increased with increase of size of unit because of availability of more space to accommodate the trees on the other hand the number of coconut trees on acre basis ranged from 79 to 230 with a decreasing trend towards higher size plot. This indicates that the density of coconut trees is significantly higher in smaller size unit than the larger size unit. However the values beyond 0.8 acre were statistically at par with each other. This signifies that towards higher holding sizes the spacing of coconut trees maintained is more or less same. The number of timber species varied from 0 to 6 per holding. In holding size of 1.3 acre to 1.5 acre less number of timber species was found to be grown with coconut. This means towards higher holding sizes people prefer less mixture of perennial plants In terms of number of timber species per acre basis significantly higher number of plants was found in relatively smaller size of plot. On others the number of timber species in coconut based agroforestry system decreased with increase of holding size. It varied from 0 to 27 numbers per acre. This reflects that the smaller size plots are comparatively denser because of more number of trees per unit area 
than the higher size plots. In higher size plot like $T_{13}, T_{14}$ and $T_{15}$ no other trees are present.

The number of fruit species other than coconut also found differently per holding in different size of unit. 2 to 7 number of fruit species were found per holding from 0.1acre to 1.1 acre and no fruit trees were found under coconut based agroforestry system. With regards to number of fruit species per acre the number was significantly higher in smaller size holding than the larger size holding. It ranged from 0 to 33. Like coconut trees and timber species the fruit species were found more per unit area in comparatively small size plot. This shows that people tried to accommodate different type of trees which are essential to met different kinds of produces in their plot even if the size at the plot is small. The results are in line with findings of (Jhon and Nair, 2002), (Ahmed and Rahaman, 2004) and (Ahmad et al., 2004).

\section{Common annual and seasonal crops in coconut based agroforestry system}

A number of common annual and seasonal crops were found to be grown in coconut based agroforestry in Puri district of Odisha (Table 2). In very small size holdings like 0.1 acre and 0.2 acre common annual crops were yam and turmeric. In holding size of 0.3 acre to 1.2 acre the common annual crops are papaya, yam, arrowroot and ginger. More number of annual crops was grown in relatively higher size holdings because of more availability of space as well as light on the ground. These annual crops are generally suitable to be grown under partial shade of tree canopy. (Manjunath et al., 1998), (Isaac and Nair, 2000) and (Maheswarappa et al., 2000) have reported similar findings. However in comparatively large plots like 1.3acre and more no annual crops were found because in such plots paddy was only grown with coconut. With regards to common seasonal crops all holding sizes exerted crops in all the three season such as kharif, rabi and summer along with coconut trees. In kharif the common seasonal were brinjal, okra, bitter gourd, chilli and greens in holding size of 0.1 acre to 1.2 acre with additional crop of cowpea in relatively higher size plot. Beyond 1.2 acre paddy was mostly grown in kharif with coconut. In rabi the common crops grown were tomato, brinjal and beans up to 0.3 acre size where as additional crops like cauliflower, onion and greens were found in relatively higher size holding up to $1.2 \mathrm{acre}$. Beyond 1.2acre no rabi crops were grown under coconut. In summer the common crops were brinjal, chilli, beans up to 0.3 acre and additional crop of pumpkin in higher size plots. No seasonal crops were found to be grown beyond 1.2acre in summer. It was observed that crop diversity is more up to 1.2 acre size holdings because these holdings were mostly the homesteads and available of water source where people grow the food crops essential for them and mostly managed by the family labour. On the other hand relatively higher holding size which were more than 1.2acre are paddy is grown in kharif and the coconut trees are located in the bunds of paddy field. Raising of different seasonal crops has also been reported by Nair (1986), (Manjunath et al., 1998) and (Isacc and Nair, 2000).

\section{Livestock in coconut based agroforestry system}

The livestock comprising animals and birds was found to be an integral part in most of the holdings size in coconut based agroforestry system in Puri district (Table 3). The animal included cattle, buffalo and goat among which cattle was common in all size holding. The cattle number varied from 2 to 4 per holding with relatively higher number with higher holdings. Keeping of cattle is very common in 
rural areas of Odisha for milk and ploughing the land. Relatively more number is found where area is more to be ploughed. The buffalo were found in holding size of 0.3 acre to 1.3 acre numbering 2 to 3 per holding. In relatively small size as well as big size holding they were not found. This may be attributed to there no space for ploughing in smaller size as well as in large area where generally mechanized farming is practised. The goats were found in holding size of 0.1 acre to 0.9 acre. This indicates that small farmers having less land are preferring goat and the number varies 2-4 per holding. The total number of animal per holding varied from 4-9 with relatively more number between 0.4 and 1.0acre. This may be due to the fact that the middle size holding are preferring all three types of livestock. Integration of livestock in coconut based agroforestry system has also been reported by (Sahoo, 2007), (Alam and Masom, 2005), (Nair and Sreedharan, 1986) and (Nair, 1983). With regards to birds poultry and ducks were found to be reared in different sizes of holding, 4-6 number of poultry bird was found up to the holding size 0.8acre. This signifies that the small farmers having relatively small area are integrating the poultry bird to enhance their income. Ducks were found to be reared in 2 to 5 numbers in the holding size varying from 0.1acre to 1.2acre. This is because ponds are available in the backyards of Puri district and ducks are reared easily for egg and meat. Beyond 1.2acre holding sizes which are mostly paddy field ducks are not found because of absence of pond. The total numbers of birds in terms of poultry and duck varied from 2 to 10 in holding size of 0.1 acre to 1.2 acre.

Table.1 Number of common perennial plant species in coconut based agroforestry system in Puri district of Odisha

\begin{tabular}{|c|c|c|c|c|c|c|}
\hline & \multicolumn{2}{|c|}{ Coconut tree } & \multicolumn{2}{c|}{ Timber species } & \multicolumn{2}{c|}{$\begin{array}{c}\text { Fruit species other than } \\
\text { coconut }\end{array}$} \\
\hline $\begin{array}{l}\text { Treatment } \\
\text { (Holding size) }\end{array}$ & $\begin{array}{c}\text { Per } \\
\text { holding }\end{array}$ & Per acre & $\begin{array}{c}\text { Per } \\
\text { holding }\end{array}$ & Per acre & $\begin{array}{c}\text { Per } \\
\text { holding }\end{array}$ & Per acre \\
\hline $\mathbf{T}_{\mathbf{1}}(\mathbf{0 . 1}$ acre) & 25 & 230 & 3 & 27 & 3 & 33 \\
\hline $\mathbf{T}_{\mathbf{2}}(\mathbf{0 . 2}$ acre) & 38 & 188 & 3 & 15 & 4 & 20 \\
\hline $\mathbf{T}_{\mathbf{3}}(\mathbf{0 . 3}$ acre) & 50 & 166 & 4 & 12 & 4 & 12 \\
\hline $\mathbf{T}_{\mathbf{4}}(\mathbf{0 . 4}$ acre) & 59 & 147 & 5 & 12 & 4 & 10 \\
\hline $\mathbf{T}_{\mathbf{5}}(\mathbf{0 . 5}$ acre) & 63 & 126 & 5 & 9 & 5 & 10 \\
\hline $\mathbf{T}_{\mathbf{6}}(\mathbf{0 . 6}$ acre) & 65 & 109 & 5 & 8 & 5 & 8 \\
\hline $\mathbf{T}_{\mathbf{7}}(\mathbf{0 . 7}$ acre) & 66 & 95 & 6 & 8 & 5 & 7 \\
\hline $\mathbf{T}_{\mathbf{8}}(\mathbf{0 . 8}$ acre) & 66 & 82 & 6 & 8 & 7 & 9 \\
\hline $\mathbf{T}_{\mathbf{9}}(\mathbf{0 . 9}$ acre) & 68 & 76 & 4 & 4 & 3 & 3 \\
\hline $\mathbf{T}_{\mathbf{1 0}}(\mathbf{1 . 0}$ acre) & 72 & 72 & 4 & 4 & 3 & 3 \\
\hline $\mathbf{T}_{\mathbf{1 1}}(\mathbf{1 . 1}$ acre) & 85 & 77 & 3 & 2 & 2 & 2 \\
\hline $\mathbf{T}_{\mathbf{1 2}}(\mathbf{1 . 2}$ acre) & 92 & 77 & 3 & 2 & 0 & 0 \\
\hline $\mathbf{T}_{\mathbf{1 3}}(\mathbf{1 . 3}$ acre) & 100 & 77 & 0 & 0 & 0 & 0 \\
\hline $\mathbf{T}_{\mathbf{1 4}}(\mathbf{1 . 4}$ acre) & 110 & 78 & 0 & 0 & 0 & 0 \\
\hline $\mathbf{T}_{\mathbf{1 5}}(\mathbf{1 . 5}$ acre) & 118 & 79 & 0 & 0 & 0 & 0 \\
\hline $\mathbf{S E}_{\mathbf{m}( \pm)}$ & $\mathbf{1 . 6 8}$ & $\mathbf{4 . 6 6}$ & $\mathbf{0 . 3 1}$ & $\mathbf{1 . 2 6}$ & $\mathbf{0 . 2 2}$ & $\mathbf{1 . 1 7}$ \\
\hline $\mathbf{C D}_{(\mathbf{0 . 0 5}}$ & $\mathbf{4 . 8 9}$ & $\mathbf{1 3 . 5 1}$ & $\mathbf{0 . 9 2}$ & $\mathbf{3 . 6 7}$ & $\mathbf{0 . 6 5}$ & $\mathbf{3 . 3 8}$ \\
\hline
\end{tabular}


Table. 2 Common annual and seasonal crops in different coconut based agroforestry system in Puri district of Odisha

\begin{tabular}{|c|c|c|c|c|}
\hline \multirow{3}{*}{$\begin{array}{c}\begin{array}{c}\text { Treatment } \\
\text { (Holding size) }\end{array} \\
\mathbf{T}_{1}(\mathbf{0 . 1} \text { acre })\end{array}$} & \multirow{3}{*}{$\begin{array}{l}\begin{array}{c}\text { Common Annual } \\
\text { crops }\end{array} \\
\text { Yam, Turmeric }\end{array}$} & \multicolumn{3}{|c|}{ Common Seasonal crops } \\
\hline & & Kharif & Rabi & Summer \\
\hline & & $\begin{array}{l}\text { Brinjal, Okra, Bitter gourd, } \\
\text { Chilli, Greens }\end{array}$ & Tomato, Brinjal, Beans & $\begin{array}{l}\text { Brinjal, Chilli, } \\
\text { Greens }\end{array}$ \\
\hline $\mathrm{T}_{2}(0.2$ acre $)$ & $\begin{array}{l}\text { Yam, Turmeric, } \\
\text { Arrowroot }\end{array}$ & $\begin{array}{l}\text { Brinjal, Okra, Bitter gourd, } \\
\text { Chilli, Greens }\end{array}$ & Tomato, Brinjal, Beans & $\begin{array}{l}\text { Brinjal, Chilli, } \\
\text { Greens }\end{array}$ \\
\hline$T_{3}(0.3$ acre $)$ & $\begin{array}{l}\text { Pine apple, Yam, } \\
\text { Arrowroot, } \\
\text { Turmeric, }\end{array}$ & $\begin{array}{l}\text { Brinjal, Okra, Bitter gourd, } \\
\text { Chilli, Greens }\end{array}$ & Tomato, Brinjal, Beans & $\begin{array}{l}\text { Brinjal, Chilli, } \\
\text { Greens }\end{array}$ \\
\hline $\mathrm{T}_{4}(0.4$ acre $)$ & $\begin{array}{l}\text { Pine apple, Yam, } \\
\text { Arrowroot, } \\
\text { Turmeric }\end{array}$ & $\begin{array}{l}\text { Brinjal, Okra, Bitter gourd, } \\
\text { Ridge gourd, Chilli, Greens, } \\
\text { Coe pea }\end{array}$ & $\begin{array}{l}\text { Tomato, } \\
\text { Cauliflower, } \\
\text { Greens }\end{array}$ & $\begin{array}{l}\text { Brinjal, Chilli, } \\
\text { Pumpkin, Greens }\end{array}$ \\
\hline $\mathrm{T}_{5}(0.5$ acre $)$ & $\begin{array}{l}\text { Pine apple, Yam, } \\
\text { Arrowroot, } \\
\text { Turmeric, Ginger }\end{array}$ & $\begin{array}{l}\text { Brinjal, Okra, Bitter gourd, } \\
\text { Ridge gourd, Chilli, Greens, } \\
\text { Coe pea }\end{array}$ & $\begin{array}{l}\text { Tomato, } \\
\text { Cauliflower, } \\
\text { Greens }\end{array}$ & $\begin{array}{l}\text { Brinjal, Chilli, } \\
\text { Pumpkin, Greens }\end{array}$ \\
\hline $\mathrm{T}_{6}(0.6$ acre $)$ & $\begin{array}{l}\text { Pine apple, Yam, } \\
\text { Arrowroot, } \\
\text { Turmeric, Ginger }\end{array}$ & $\begin{array}{l}\text { Brinjal, Okra, Bitter gourd, } \\
\text { Ridge gourd, Chilli, Greens, } \\
\text { Cow pea }\end{array}$ & $\begin{array}{l}\text { Tomato, } \\
\text { Cauliflower, } \\
\text { Greens }\end{array}$ & $\begin{array}{l}\text { Brinjal, Chilli, } \\
\text { Pumpkin, Greens }\end{array}$ \\
\hline $\mathrm{T}_{7}(0.7$ acre $)$ & $\begin{array}{l}\text { Pine apple, Yam, } \\
\text { Arrowroot, } \\
\text { Turmeric, Ginger }\end{array}$ & $\begin{array}{l}\text { Brinjal, Okra, Bitter gourd, } \\
\text { Ridge gourd, Chilli, Greens, } \\
\text { Cow pea }\end{array}$ & $\begin{array}{l}\text { Tomato, } \quad \text { Brinjal, } \\
\text { Cabbage, Cauliflower, } \\
\text { Onion, Greens }\end{array}$ & $\begin{array}{l}\text { Brinjal, Chilli, } \\
\text { Pumpkin, Greens }\end{array}$ \\
\hline $\mathrm{T}_{8}(0.8$ acre $)$ & $\begin{array}{l}\text { Pine apple, Yam, } \\
\text { Arrowroot, } \\
\text { Turmeric, Ginger }\end{array}$ & $\begin{array}{l}\text { Brinjal, Okra, Bitter gourd, } \\
\text { Ridge gourd, Chilli, Greens, } \\
\text { Cow pea }\end{array}$ & $\begin{array}{l}\text { Tomato, Brinjal, } \\
\text {,Cauliflower, Greens }\end{array}$ & $\begin{array}{l}\text { Brinjal, Chilli, } \\
\text { Pumpkin, Greens }\end{array}$ \\
\hline$T_{9}(0.9$ acre $)$ & $\begin{array}{l}\text { Pine apple, Yam, } \\
\text { Arrowroot, } \\
\text { Turmeric, Ginger }\end{array}$ & $\begin{array}{l}\text { Brinjal, Okra, Bitter gourd, } \\
\text { Ridge gourd, Chilli, Greens, } \\
\text { Cow pea }\end{array}$ & $\begin{array}{l}\text { Tomato, Brinjal, } \\
\text { Cauliflower, Greens }\end{array}$ & $\begin{array}{l}\text { Brinjal, Chilli, } \\
\text { Pumpkin, Greens }\end{array}$ \\
\hline$T_{10}(1.0$ acre $)$ & $\begin{array}{l}\text { Pine apple, Yam, } \\
\text { Arrowroot, } \\
\text { Turmeric, Ginger }\end{array}$ & $\begin{array}{l}\text { Brinjal, Okra, Bitter gourd, } \\
\text { Ridge gourd, Chilli, Greens, } \\
\text { Cow pea }\end{array}$ & $\begin{array}{l}\text { Tomato, Brinjal, } \\
\text { Cauliflower, Greens }\end{array}$ & $\begin{array}{l}\text { Brinjal, Chilli, } \\
\text { Pumpkin, Greens }\end{array}$ \\
\hline$T_{11}(1.1$ acre $)$ & $\begin{array}{l}\text { Pine apple, Yam, } \\
\text { Arrowroot, } \\
\text { Turmeric, Ginger }\end{array}$ & $\begin{array}{l}\text { Brinjal, Okra, Bitter gourd, } \\
\text { Ridge gourd, Chilli, Greens, } \\
\text { Cow pea }\end{array}$ & $\begin{array}{l}\text { Tomato, Brinjal, } \\
\text { Cauliflower, Greens }\end{array}$ & $\begin{array}{l}\text { Brinjal, Chilli, } \\
\text { Pumpkin, Greens }\end{array}$ \\
\hline$T_{12}(1.2$ acre $)$ & $\begin{array}{l}\text { Pine apple, Yam, } \\
\text { Arrowroot, } \\
\text { Turmeric, Ginger }\end{array}$ & $\begin{array}{l}\text { Brinjal, Okra, Bitter gourd, } \\
\text { Ridge gourd, Chilli, Greens, } \\
\text { Cow pea }\end{array}$ & $\begin{array}{l}\text { Tomato, } \quad \text { Brinjal, } \\
\text { Cauliflower, Greens }\end{array}$ & $\begin{array}{l}\text { Brinjal, Chilli, } \\
\text { Pumpkin, Greens }\end{array}$ \\
\hline$T_{13}(1.3$ acre $)$ & - & Paddy & - & - \\
\hline$T_{14}(1.4$ acre $)$ & - & Paddy & - & - \\
\hline$T_{15}(1.5$ acre $)$ & - & Paddy & - & - \\
\hline
\end{tabular}


Table.3 Livestock in coconut based agroforestry system in Puri district of Odisha

\begin{tabular}{|c|c|c|c|c|c|c|c|}
\hline \multirow[b]{2}{*}{$\begin{array}{l}\text { Treatment } \\
\text { (Holding } \\
\text { size) }\end{array}$} & \multicolumn{4}{|c|}{ Number of animals } & \multicolumn{3}{|c|}{ Number of birds } \\
\hline & Cattle & Buffalo & Goat & Total & Poultry & Duck & Total \\
\hline$T_{1}(0.1$ acre $)$ & 2 & 0 & 2 & 4 & 6 & 5 & 10 \\
\hline $\mathrm{T}_{2}(0.2$ acre $)$ & 2 & 0 & 3 & 5 & 6 & 4 & 9 \\
\hline$T_{3}(0.3$ acre $)$ & 2 & 0 & 4 & 6 & 6 & 4 & 10 \\
\hline $\mathrm{T}_{4}(0.4$ acre $)$ & 2 & 2 & 3 & 7 & 5 & 4 & 9 \\
\hline$T_{5}(0.5$ acre $)$ & 2 & 2 & 3 & 7 & 5 & 3 & 8 \\
\hline$T_{6}(0.6$ acre $)$ & 3 & 2 & 3 & 8 & 5 & 3 & 8 \\
\hline $\mathrm{T}_{7}(0.7$ acre $)$ & 3 & 2 & 3 & 8 & 4 & 3 & 7 \\
\hline$T_{8}(0.8$ acre $)$ & 3 & 2 & 4 & 9 & 4 & 3 & 7 \\
\hline$T_{9}(0.9$ acre $)$ & 4 & 2 & 2 & 8 & 0 & 5 & 5 \\
\hline$T_{10}(1.0$ acre $)$ & 4 & 3 & 0 & 7 & 0 & 4 & 4 \\
\hline$T_{11}(1.1$ acre $)$ & 4 & 2 & 0 & 6 & 0 & 3 & 3 \\
\hline$T_{12}(1.2$ acre $)$ & 4 & 2 & 0 & 6 & 0 & 2 & 2 \\
\hline$T_{13}(1.3$ acre $)$ & 4 & 2 & 0 & 6 & 0 & 0 & 0 \\
\hline$T_{14}(1.4$ acre $)$ & 4 & 0 & 0 & 4 & 0 & 0 & 0 \\
\hline$T_{15}(1.5$ acre $)$ & 4 & 0 & 0 & 4 & 0 & 0 & 0 \\
\hline $\mathrm{CD}(0.05)$ & 1.09 & 1.08 & 1.68 & 1.28 & 1.03 & 0.79 & 0.61 \\
\hline $\operatorname{SEm}( \pm)$ & 0.37 & 0.37 & 0.58 & 0.44 & 0.36 & 0.27 & 0.21 \\
\hline
\end{tabular}

Fig.1 Pisciculture in coconut based agroforestry system

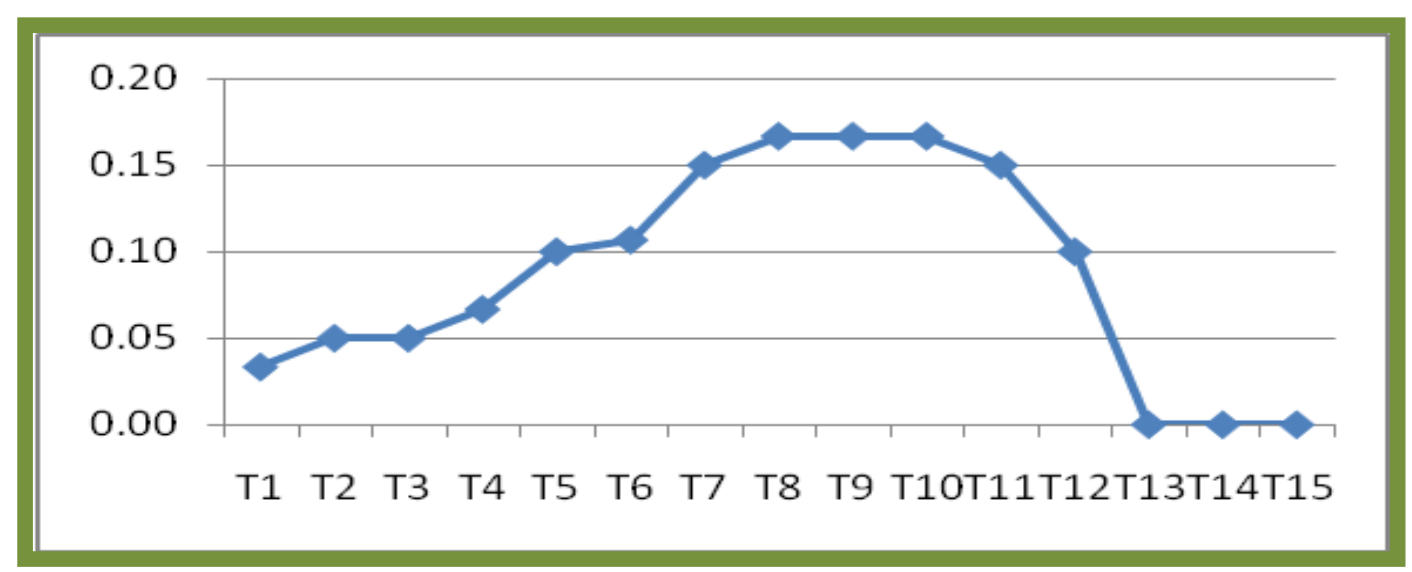


Fig.2 Mushroom cultivation in coconut based agroforestry system

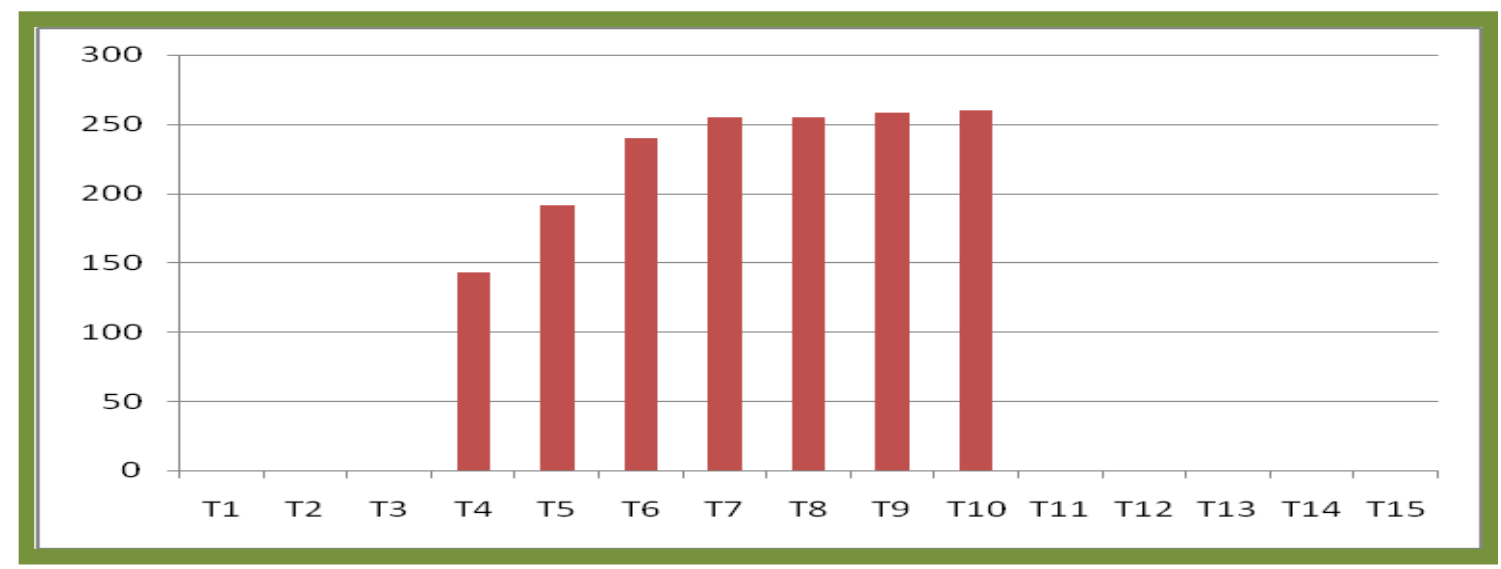

Significantly higher numbers of birds were found in relatively smaller size holding because people try to enhance their income by integrating more number of birds in their small size holdings. Rearing of birds in coconut based agroforestry also been reported by (Jhon and Nair, 1999), (Ahmed and Hazarika, 2007) and (Nair, 2008).

\section{Pisciculture in coconut based agroforestry system}

In costal district like Puri presence of pond is a common feature in the homestead (Fig. 1) which provides scope for pisciculture in coconut based agroforestry system. It was observed that fish pond of size 0.03acre to 0.17 acre was available in the homestead around which coconut and other trees were grown. Relatively higher size of pond was found between 0.4 acre and 1.2acre holding size. Beyond 1.2acre ponds are not available because these are paddy field and fish cultivation is not practised. 2-3 numbers of fish species were found to be cultivated by people and they are mostly rohi, silver cup and grass cup. People grow these species for home consumption in case of small size pond and some extend for sale in higher size pond.

\section{Mushroom cultivation in coconut based agroforestry system}

Integration of paddy straw and oyster mushroom is increasing in the coconut based agroforestry system in Puri district (Fig 2). It was observed that holding size of 0.4 acre to 1.00 acre are accommodating mushroom cultivation under the canopy of coconut. This indicates that farmers have medium size holding around their homestead were preferring mushroom cultivation. The reason is that the microclimate under canopy of coconut is suitable for paddy straw and there is a good market for the mushroom due to presence of big cities like Bhubaneswar, Cuttack and Puri.

In conclusion, the findings of the present study indicate that the treatments upto 1.2acre size were found to be well composed of various types of plants such as tree species, fruit plants and seasonal crops along with coconut in four different layers. The livestock such as cattle, buffalo, goat, ducks and poultry are associated in most of the coconut based agroforestry systems. Coconut based agroforestry systems particularly upto 1.2acre size are contributing various types of tangible and intangible benefits to the households 
including food, fuel, timber, fodder, oil, thatching and broom material, cash, employment, shade, good microclimate, habitat for birds, learning ground for children, aesthetic, cultural and religious values.Out of the 15 treatments, the coconut based agroforestry system of size 0.8 acre was found to be best among the holding sizes studied with regard to various species composition.

\section{References}

Ahmed, A. A. and Hazarika, D. N. 2007. Agroforestry systems and practices prevailing in Assam. Agroforestry: systems and practices (eds. Puri, S. and Panwar, P.) pp. 347-355.

Ahmed, M. F. U. and Rahman, S. M. L. 2004. Profile and use of multi-species tree crops in the homesteads of Gazipur District, Central Bangladesh. Journal of Sustainable Agriculture 24(1): 81-93.

Ahmed, M.F.U.; Rahman, S.M.L.; Ahmed, A.S.M.M. and Quebedeaux, B. 2004. Agroforestry as it pertains to vegetable production in Bangladesh. Journal of Agronomy 3(4): 282-290.

Alam, M. S. and Masum, K. M. 2005. Status of homestead biodiversity in the offshore island of Bangladesh. Research Journal of Agriculture and Biological Sciences 1(3): 246-253.

Fernandes, E.C.M., O'Kting'ati, A. and Maghembe, J. 1984. The Chagga homegardens: A multistoried agroforestry cropping system on Mt. Kilimanjaro, Northern Tanzania. Agroforestry Systems 2: 73-86.

Isaac, S.R. and Nair, M. A. 2000. Coconut gardens for agroforestry. Indian Coconut Journal 31(3): 14-16.

John, J. and Nair, M. A. 1999. Socio economic characteristics of homestead farming in south Kerala. Journal of Tropical Agriculture 37(1/2): 107-109

John, J. and Nair, M. A. 2002. Differences with holding size in the composition of coconut based homesteads of Southern Kerala. Indian Coconut Journal 33(5): 7-10.

Maheswarappa, H. P.; Hegde, M. R. and Nanjappa, H. V. 2000. Arrowroot (Maranta arundinacea L.): a potential intercrop in coconut garden. Indian Coconut Journal 31(3): 20-21.

Manjunath, B. L.; Balbatti, M. S. and Dhandar, D. G. 1998. Intercropping in coconut for higher monetary returns. Developments in plantation crops research Proceedings of the $12^{\text {th }}$ Symposium on Plantation Crops, PLACROSYM-XII, Kottayam, India 199-202pp.

Nair, M. A. and Sreedharan, C. 1986. Agroforestry Farming Systems in the Homesteads of Kerala, Southern India. Indian Journal of Arecanut, Spices and Medicinal Plants 5(1): 23-30.

Nair, P. K. R. 2008. Structure and function of Home gardens. An Introduction to Agroforestry (eds. Nair, P.K.R.) pp.9194.

Rahman, S. A.; Baldauf, C.; Mollee, E. M.; Al-Pavel, M. A.; Al-Mamun, M. A.; Toy, M. M. and Sunderland, T. 2013. Cultivated Plants in the Diversified Homegardens of Local Communities in Ganges Valley, Bangladesh. Science Journal of Agricultural Research and Management Volume 2013, Article ID sjarm-197, pp 6.

Sahoo, U. K. 2007. Agroforestry systems and practices prevailing in Mizoram. Agroforestry: systems and practices (eds. Puri, S. and Panwar, P.) pp. 367383. 


\section{How to cite this article:}

Sarangi, S. K., N. K. Panda and Bhol, N. 2020. Species Diversity in Coconut (Cocos nucifera) based Agroforestry System in Coastal Odisha. Int.J.Curr.Microbiol.App.Sci. 9(08): 61-70. doi: https://doi.org/10.20546/ijcmas.2020.908.007 